\title{
Biogeography and morphology of a poorly known diatom Dorofeyukea rostellata (Hustedt) Kulikovskiy \& Kociolek
}

\author{
Zsuzsa Trábert ${ }^{1,2, *}$, Krisztina Buczkó1,3, Gábor Borics ${ }^{4}$, Marija Gligora Udovič ${ }^{5}$, Balasubramanian \\ Karthick $^{6}$, Luc Ector ${ }^{7}$, Angéla Földi ${ }^{1,2}$, Keve T. Kiss ${ }^{1}$ and Éva Ács ${ }^{1}$ \\ ${ }_{1}^{1}$ MTA Centre for Ecological Research, Danube Research Institute, 1113 Budapest, Karolina út 29, Hungary. \\ 2 Eötvös Loránd University, Doctoral School of Environmental Sciences, 1117 Budapest, Pázmány Péter sétány \\ 1/A, Hungary. \\ 3 Hungarian Natural History Museum, Department of Botany, 1087 Budapest, Könyves Kálmán krt. 40, Hungary. \\ 4 MTA Centre for Ecological Research, Danube Research Institute, Department of Tisza River Research, 4026 \\ Debrecen, Bem tér 18/c, Hungary. \\ 5 Department of Biology, Faculty of Science, University of Zagreb, 10000 Zagreb, Rooseveltov trg 6, Croatia. \\ 6 Biodiversity \& Paleobiology Group, Agharkar Research Institute, G.G. Agarkar Road, Pune - 411004 India. \\ 7 Environmental Research and Innovation Department (ERIN), Institute of Science and Technology (LIST), \\ 4422 Belvaux, 41 rue du Brill, Luxembourg. \\ *Corresponding author: trabert.zsuzsa@okologia.mta.hu
}

Received: 04/04/18 Accepted: 29/01/19

\begin{abstract}
Biogeography and morphology of a poorly known diatom Dorofeyukea rostellata (Hustedt) Kulikovskiy \& Kociolek

Dorofeyukea rostellata is a rare and poorly known representative of Dorofeyukea genus. To date, this taxon has only been recorded only outside of Europe. In two Croatian lakes, we found a diatom in appearance similar to Dorofeyukea rostellata and within corresponding physical and chemical conditions. Due to the uncertain taxonomical position of this taxon, type material of Dorofeyukea rostellata and a closely related species, Navicula grimmeioides, were analysed by means of light and scanning electron microscopy. Upon a detailed investigation, we could clearly distinguish the Croatian population from $N$. grimmeioides. However, the Croatian population and the type material of D. rostellata differed only in minor characteristics. The most obvious difference is the shape of areolae. Nevertheless, differences between the shapes of the areolae can be caused by the degree of silicification, which often depends on the environmental conditions. Since almost every other characteristic of the Croatian population overlapped with that of the type material of $D$. rostellata we identified it as $D$. rostellata. Additionally, scanning electron microscopy analyses also revealed that $N$. grimmeioides belongs to the genus Dorofeyukea, so its new combination was proposed.
\end{abstract}

Key words: type material, Dorofeyukea rostellata, Navicula grimmeioides, calcareous habitat, new combination

\section{RESUMEN}

\section{Biogeografía y morfología de una diatomea poco conocida Dorofeyukea rostellata (Hustedt) Kulikovskiy \& Kociolek}

Dorofeyukea rostellata es un representante raro y poco conocido del género Dorofeyukea. Hasta la fecha, esta especie solo ha sido registrada fuera de Europa. En dos lagos croatas, encontramos una diatomea en apariencia similar a Dorofeyukea rostellata y en las condiciones físicas y químicas correspondientes. Debido a la incierta posición taxonómica de este taxón, el material tipo de Dorofeyukea rostellata y una especie estrechamente relacionada, Navicula grimmeioides, se analizaron mediante microscopía de luz y electrónica de barrido. Tras una investigación detallada, pudimos distinguir claramente la población croata de N. grimmeioides. Sin embargo, la población croata y el tipo de material de D. rostellata diferían solo en características menores. La diferencia más obvia es la forma de las areolas. Sin embargo, las diferencias pueden deberse al grado de silicificación, que a menudo depende de las condiciones ambientales. Como casi todas las demás características de 
la población croata se superponían con del material tipo de D. rostellata, lo identificamos como D. rostellata. Además, los análisis de microscopía electrónica de barrido también revelaron que $\mathrm{N}$. grimmeioides también pertenece al género Dorofeyukea, por lo que se propuso una nueva combinación.

Palabras clave: ejemplares tipo, Dorofeyukea rostellata, Navicula grimmeioides, hábitat calcáreo, nueva combinación

\section{INTRODUCTION}

Navicula grimmei var. rostellata Hustedt (1937, p. 236, fig. 13) was described from Indonesia in 1937 as a variety of Navicula grimmei Krasske. Kulikovskiy et al. (2019) transferred them into a newly erected genus Dorofeyukea, which was described on the basis of DNA sequence and morphological data as Dorofeyukea rostellata (Hustedt) Kulikovskiy \& Kociolek and Dorofeyukea grimmei (Krasske in Hustedt) Kulikovskiy \& Kociolek.

Distribution of Dorofeyukea rostellata is sporadic but wide and disparate (Fig. 1a); it was first recorded in the tropical equatorial lakes of Central Java and in warm springs in Central Sumatra (Hustedt, 1937). It was also recorded from Antarctica, in the sediment from King George Island (Kim \& Park, 1988) as Navicula grimmei var. rostellata. The identity of the diatom documented by Kim \& Park (1988) is ambiguous. However, the species found by Kim $\&$ Park is not Dorofeyukea rostellata based on the attached images according to Kim \& Park's publication (1988). Consequently, we put it on the world map as formally noticed occurrence. Another occurrence of this taxon comes from Ghana (Smith et al., 2015).

To study and assess the ecological potential of Croatian reservoirs, a country-wide survey was organised in 2016 and 2017. In some of the benthic samples, we found a diatom population similar to the members of genus Dorofeyukea with characteristic isodiametric areola (Potapova, 2013). We referred to it as 'Croatian population' in the followings. The most characteristic features of the taxon resembled Dorofeyukea grimmei. Consequently, we overviewed the taxa closely related to Dorofeyukea grimmei. Based on main characters we concluded that the reinvestigation of the original material is necessary to confirm the identification. The analyses of the type materials of Dorofeyukea rostellata and Navicula grimmeioides H.P. Gandhi in light (LM) and scanning electron microscopy (SEM) were carried out to clarify the identity of the Croatian diatom taxon. Our goal was to give an emended description of the ultrastructure of the studied taxa.

\section{MATERIALS AND METHODS}

\section{Sampling}

The Croatian standard diatom sampling methodology in water quality assessments of rivers and lakes was used in Croatia (Narodne Novine, 73/2013, 151/2014 and 78/2015). Sampling was performed in two artificial lakes Ričice and Tribalj following the "single habitat sampling" principle (Barbour et al., 1999). As there were no stones as representative microhabitats at either of the sampling points, mud in the Lake Ričice (43.51065 ${ }^{\circ} \mathrm{N}, 17.11951^{\circ} \mathrm{E}$ ) and technolital (concrete) in Lake Tribalj (at $45.22876{ }^{\circ} \mathrm{N}, 14.66736{ }^{\circ} \mathrm{E}$ and $45.22651^{\circ} \mathrm{N}, 14.67109^{\circ} \mathrm{E}$ sampling points) were sampled on 22th July and 8th September in 2016, respectively (Fig. 1b). Five sub-samples were sampled at each sampling site. All samples were preserved with $4 \%$ formaldehyde.

The following environmental variables were recorded at each sampling point during the sampling: water temperature $\left({ }^{\circ} \mathrm{C}\right), \mathrm{pH}$, electric conductivity $(\mu \mathrm{S} / \mathrm{cm})$, dissolved oxygen $(\mathrm{mg} / \mathrm{L})$, oxygen saturation (\%). Other variables were detected only in one point in each lake: alkalinity $(\mathrm{mg} / \mathrm{L})$, total hardness $(\mathrm{mg} / \mathrm{L})$, turbidity (NTU), $\mathrm{BOD}_{5} \quad(\mathrm{mg} / \mathrm{L}), \quad \mathrm{COD}-\mathrm{Mn} \quad(\mathrm{mg} / \mathrm{L}), \quad \mathrm{NH}_{4}-\mathrm{N}$ $(\mathrm{mg} / \mathrm{L}), \mathrm{NO}_{2}-\mathrm{N}(\mathrm{mg} / \mathrm{L}), \mathrm{NO}_{3}-\mathrm{N}(\mathrm{mg} / \mathrm{L})$, Total N $(\mathrm{mg} / \mathrm{L}), \mathrm{PO}_{4}-\mathrm{P}(\mathrm{mg} / \mathrm{L})$, Total $\mathrm{P}(\mathrm{mg} / \mathrm{L}), \mathrm{Ca}$ $(\mathrm{mg} / \mathrm{L}), \mathrm{Mg}(\mathrm{mg} / \mathrm{L})$ and $\mathrm{SiO}_{2}(\mathrm{mg} / \mathrm{L})$ as per standard methods for water analysis (CEN, 2014). The measured values are presented in Table 1. 


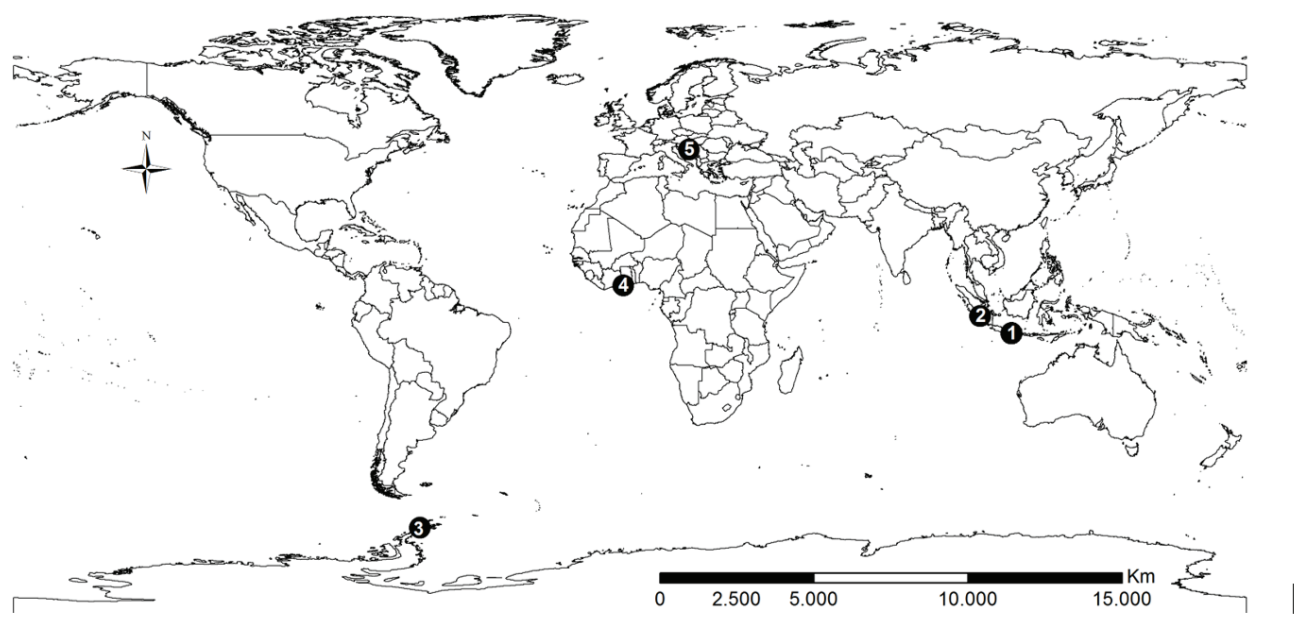

(a)

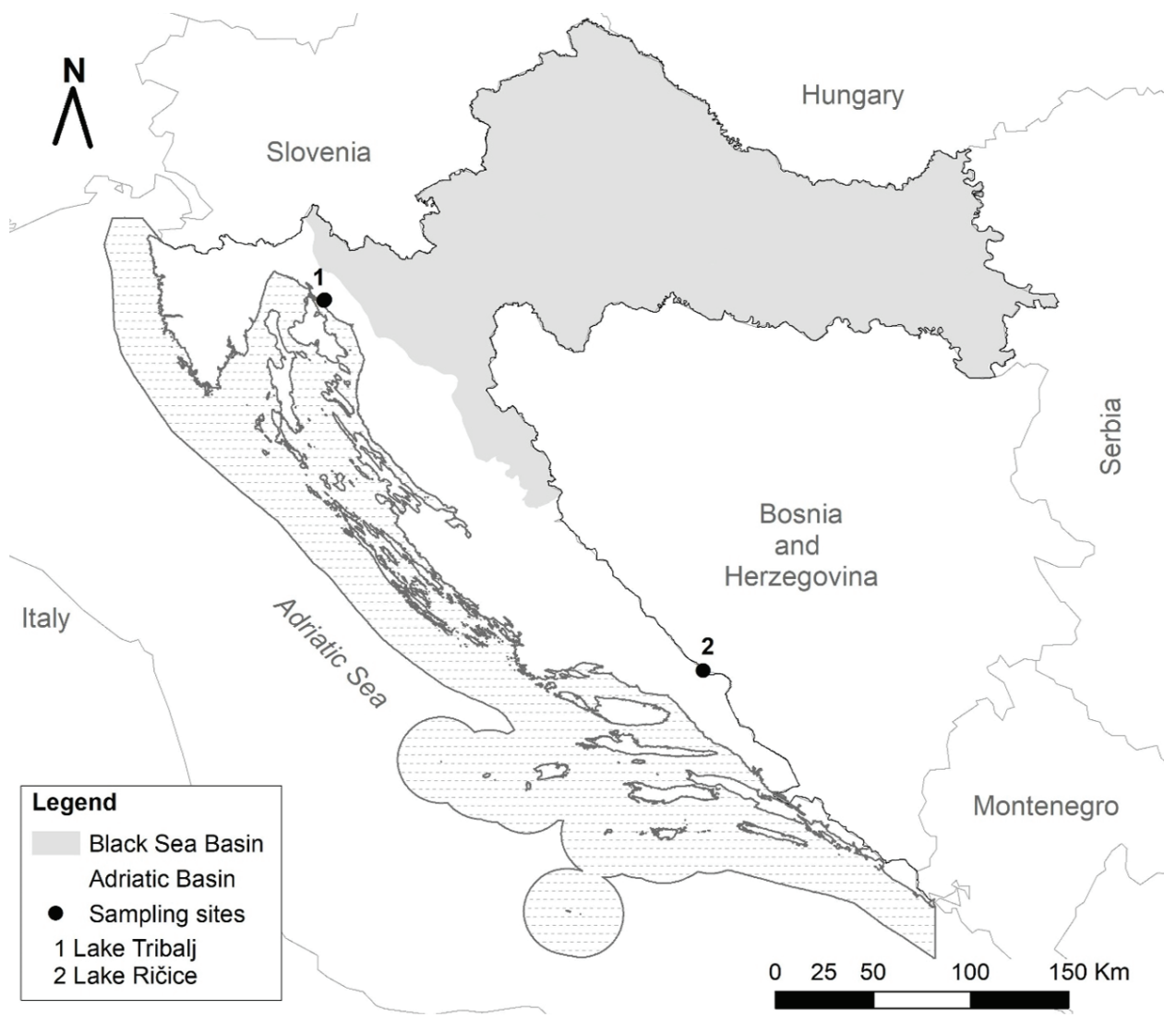

(b)

Figure 1. (a) World map distribution of Dorofeyukea rostellata (1 - Central Java, 2 - Central Sumatra, 3 - Antarctica (King George Island) (The species was recorded here but that must have been misidentification. However, we put it on the map because this occurrence of the species had formally been published.), 4 - Ghana, 5 - Lake Tribalj, Lake Ričice). Distribución mundial de Dorofeyukea rostellata. (b) Sampling localities (1 - Tribalj and 2 - Ričice lakes, Croatia). Sitios de muestreo. 
Table 1. Physical and chemical variables in sampling sites on the sampling days. Variables fisicas y químicas en sitios de muestreo en los días de muestreo.

\begin{tabular}{lcl}
\hline & Ričice & Tribalj \\
\hline Water Temperature $\left({ }^{\circ} \mathrm{C}\right)$ & 27.5 & 22.3 \\
\hline $\mathrm{pH}$ & 7.66 & 7.33 \\
\hline Conductivity $(\mu \mathrm{S} / \mathrm{cm})$ & 255 & 243 \\
\hline Dissolved oxygen $(\mathrm{mg} / \mathrm{L})$ & 7.67 & 8.78 \\
\hline Oxygen saturation $(\%)$ & 102.3 & 102.3 \\
\hline Alkalinity $(\mathrm{mg} / \mathrm{L})$ & 140.1 & 118 \\
\hline Total hardness $(\mathrm{mg} / \mathrm{L})$ & 150.2 & 149 \\
\hline Turbidity $(\mathrm{NTU})$ & 8.35 & 11.7 \\
\hline $\mathrm{BOD} 5(\mathrm{mg} / \mathrm{L})$ & 0.93 & 1.5 \\
\hline $\mathrm{COD}_{-}-\mathrm{Mn}(\mathrm{mg} / \mathrm{L})$ & 1.25 & 2 \\
\hline $\mathrm{NH}_{4}-\mathrm{N}(\mathrm{mg} / \mathrm{L})$ & 0.075 & 0.041 \\
\hline $\mathrm{NO}_{2}-\mathrm{N}(\mathrm{mg} / \mathrm{L})$ & 0.024 & 0.003 \\
\hline $\mathrm{NO}_{3}-\mathrm{N}(\mathrm{mg} / \mathrm{L})$ & 0.155 & 0.19 \\
\hline Total N $(\mathrm{mg} / \mathrm{L})$ & 0.892 & 0.41 \\
\hline $\mathrm{PO}_{4}-\mathrm{P}(\mathrm{mg} / \mathrm{L})$ & 0.0014 & 0.0031 \\
\hline Total $\mathrm{P}(\mathrm{mg} / \mathrm{L})$ & 0.003 & 0.028 \\
\hline $\mathrm{Ca}(\mathrm{mg} / \mathrm{L})$ & 50.26 & 48.3 \\
\hline $\mathrm{Mg}(\mathrm{mg} / \mathrm{L})$ & 5.88 & 6.77 \\
\hline $\mathrm{SiO}_{2}(\mathrm{mg} / \mathrm{L})$ & 3.35 & 3.6 \\
\hline
\end{tabular}

\section{Microscopic investigations}

In the laboratory, samples were rinsed with distilled water to remove formaldehyde and subsequently treated with hot $\mathrm{H}_{2} \mathrm{O}_{2}$ and mounted in Naphrax ${ }^{\circledR}$. Slides were analysed with the Olympus IX-70 light microscope $(1500 \times)$. At least 500 frustules were counted for the Croatian samples.

Using LM 46 valves of Dorofeyukea rostellata were documented in the type material and further 9 specimens in SEM. The type material of Navicula grimmeioides was observed with an Olympus BX53 DIC microscope equipped with Olympus DP73 camera and cellSens 1.13 imaging software.

A part of the cleaned and washed samples was filtered through a $3 \mu \mathrm{m}$ Isopore ${ }^{\mathrm{TM}}$ polycarbonate membrane filter (Merck Millipore, Germany) for SEM studies. The filter was fixed onto a stub using double-sided carbon tape and coated with gold using a rotary-pumped spatter coater
Quorum Q150R S (ZEISS). Fine structures of diatom frustules were observed with Zeiss EVO MA 10 SEM (ZEISS) operated at $10 \mathrm{kV}$ and 10 $\mathrm{mm}$ distance using SEM detectors in case of Croatian samples and type material of Dorofeyukea rostellata. For scanning electron microscopy of type material of Navicula grimmeioides, processed samples were air dried on the cover glass and pasted over the aluminium stubs using double-sided carbon tape. Samples were gold coated for approximately 3 minutes using an Emitech K575X sputter coater and observed with a Zeiss EVO 50 Lab 6 Scanning Electron Microscope. Observations were made under $15-20 \mathrm{kV}$ acceleration voltages at a 5-8 $\mathrm{mm}$ Working Distance. Micrographs were recorded using Zeiss SmartSEM software. Gandhi's samples used in this study are housed at Agharkar Research Institute's Diatom Herbarium, Pune. All statistical analyses were performed in $\mathrm{R}$ version 3.4.2 implemented in Windows. Maps were generated using ArcMap 10.1.

Type material of Dorofeyukea rostellata investigated: AS 745 (lectotype), 7.3.1929 (under the name Navicula grimmei var. rostellata).

LM images were taken from the powder of the lectotype material washed before mounting into Naphrax ${ }^{\circledR}$.

The studied slides of the Croatian population of Dorofeyukea rostellata are deposited in the Hungarian Natural History Museum BP-NHMUS-ALG 2300-2305.

\section{RESULTS}

Investigation of the Croatian population (Figs. 2-13, Figs. 38-57)

In LM the outline of symmetrical valves is lanceolate with slightly capitate or broadly rounded apices (Figs. 2-13). The valve length is 12.8-30.8 $\mu \mathrm{m}($ mean $=18 \pm 4.0 \mu \mathrm{m}, \mathrm{n}=26)$ and the width is 5.3-7.3 $\mu \mathrm{m}($ mean $=6.1 \pm 0.5 \mu \mathrm{m}, \mathrm{n}=26)$. Striae are radial, (slightly) convergent on the apices. The number of striae is $19-25$ in $10 \mu \mathrm{m}$ (mean = $22 \pm 1.3, \mathrm{n}=26$ ). Central area is slightly asymmetric bowtie-shaped. Axial area is narrow. Raphe is filiform. There is no stigma on the surface of the valve. 


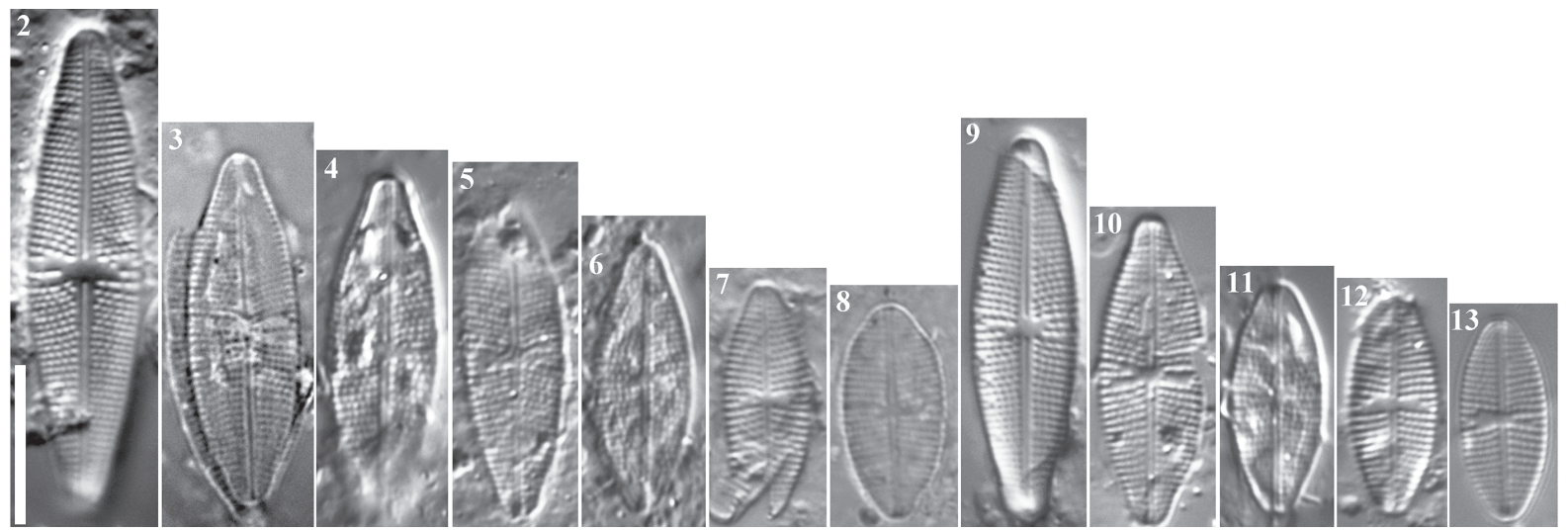

Figure 2-13. Dorofeyukea rostellata found in the Croatian lakes. LM: (Figs 2-8) from Ričice, (Figs 9-13) from Tribalj. Scale bar $=10$ $\mu \mathrm{m}$. Especies encontradas en los embalses de Croacia. MO: (Figs 2-8) de Ričice, (Figs 9-13) de Tribalj. Barra de escala = $10 \mu \mathrm{m}$.

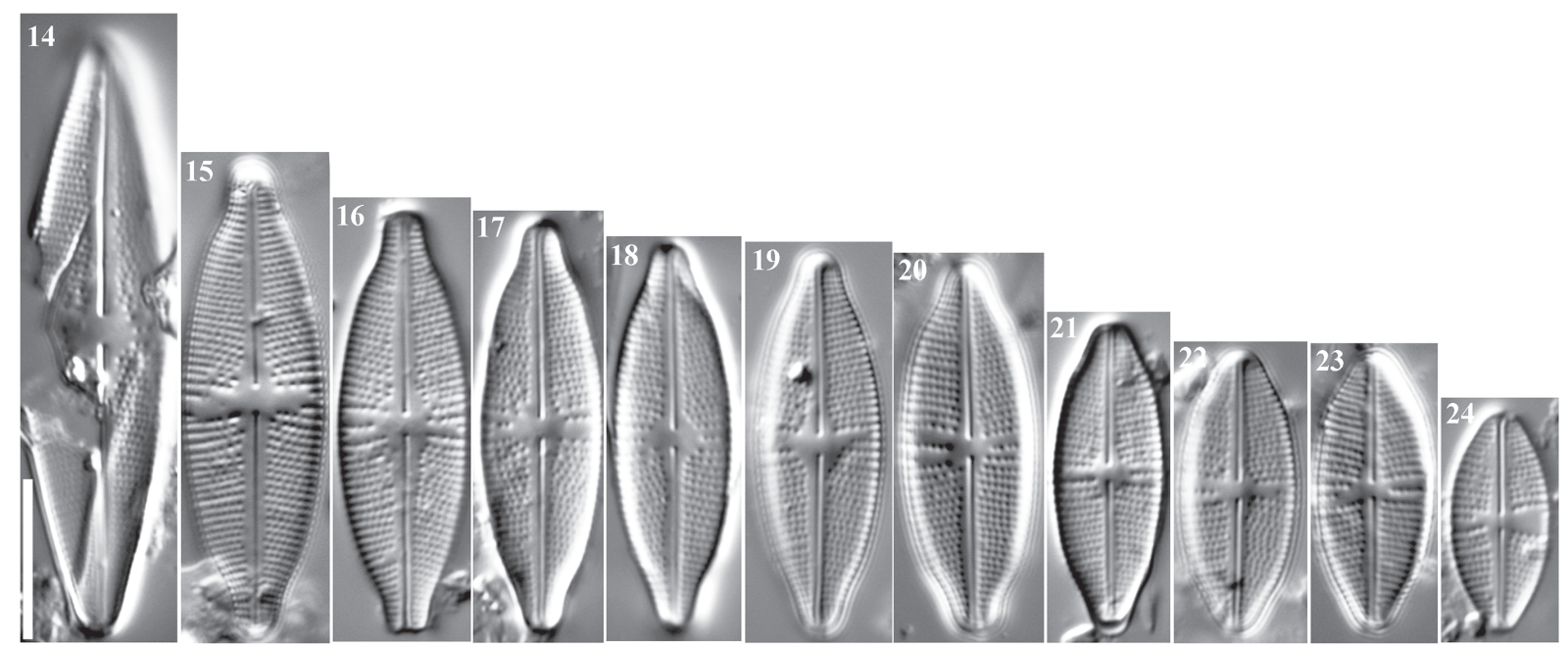

Figure 14-24. Dorofeyukea rostellata. LM micrographs of the type material. Scale bar $=10 \mu \mathrm{m}$. Dorofeyukea rostellata. Micrografias MO del material tipo. Barra de escala $=10 \mu \mathrm{m}$.

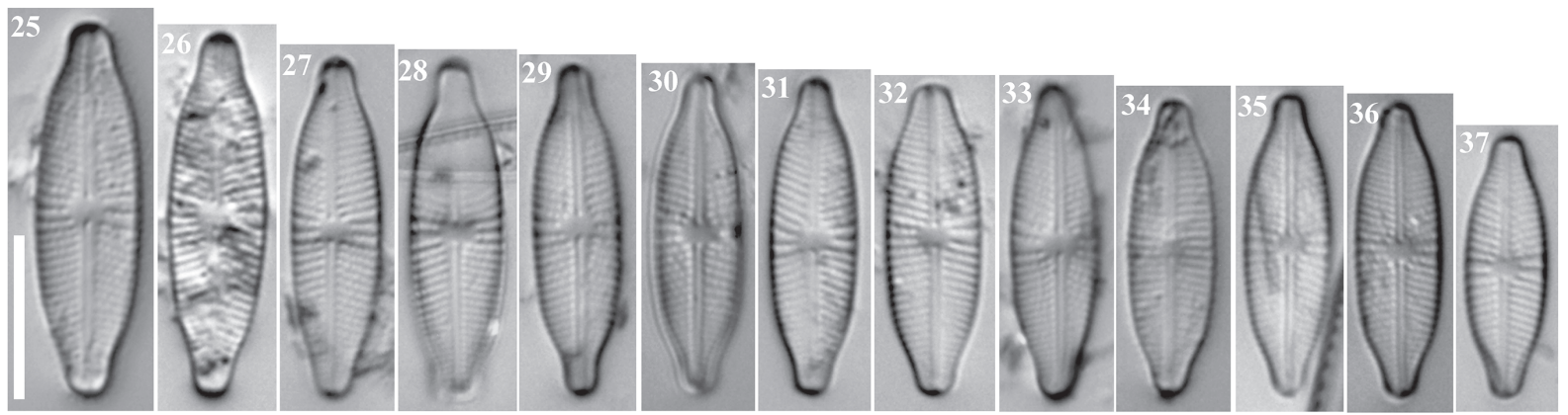

Figure 25-37. Dorofeyukea grimmeioides. LM micrographs of type material. Scale bar $=10 \mu \mathrm{m}$. Dorofeyukea grimmeioides. Micrografias $M O$ del material tipo. Barra de escala $=10 \mu \mathrm{m}$. 
In SEM (Figs. 38-57), striae are composed of single rows of elongated areolae, which continue on the mantle in several rows (Figs. 38, 41, 43). On the central area there are (1)2-3(4) striae creating an irregular hyaline field (Figs. 40, 42, $44,56)$. In the middle part of the valve the interstriae can be wider or narrower (Figs. 41, 42, 44, $45)$. Externally, the areolae are rectangular, occa- sionally transversally elongated at the central part (Fig. 55) and slit-like on the apices (Figs. 52-54). The proximal raphe fissures are straight and slightly drop-shaped.

Internally, the areolae are closed by hymens (Fig. 57). Most of them are also elongated, some of them are dot shaped (Figs. 56, 57). Number of areolae is (24) $25-30$ in $10 \mu \mathrm{m}$ (mean $=27.7 \pm 1.9$,

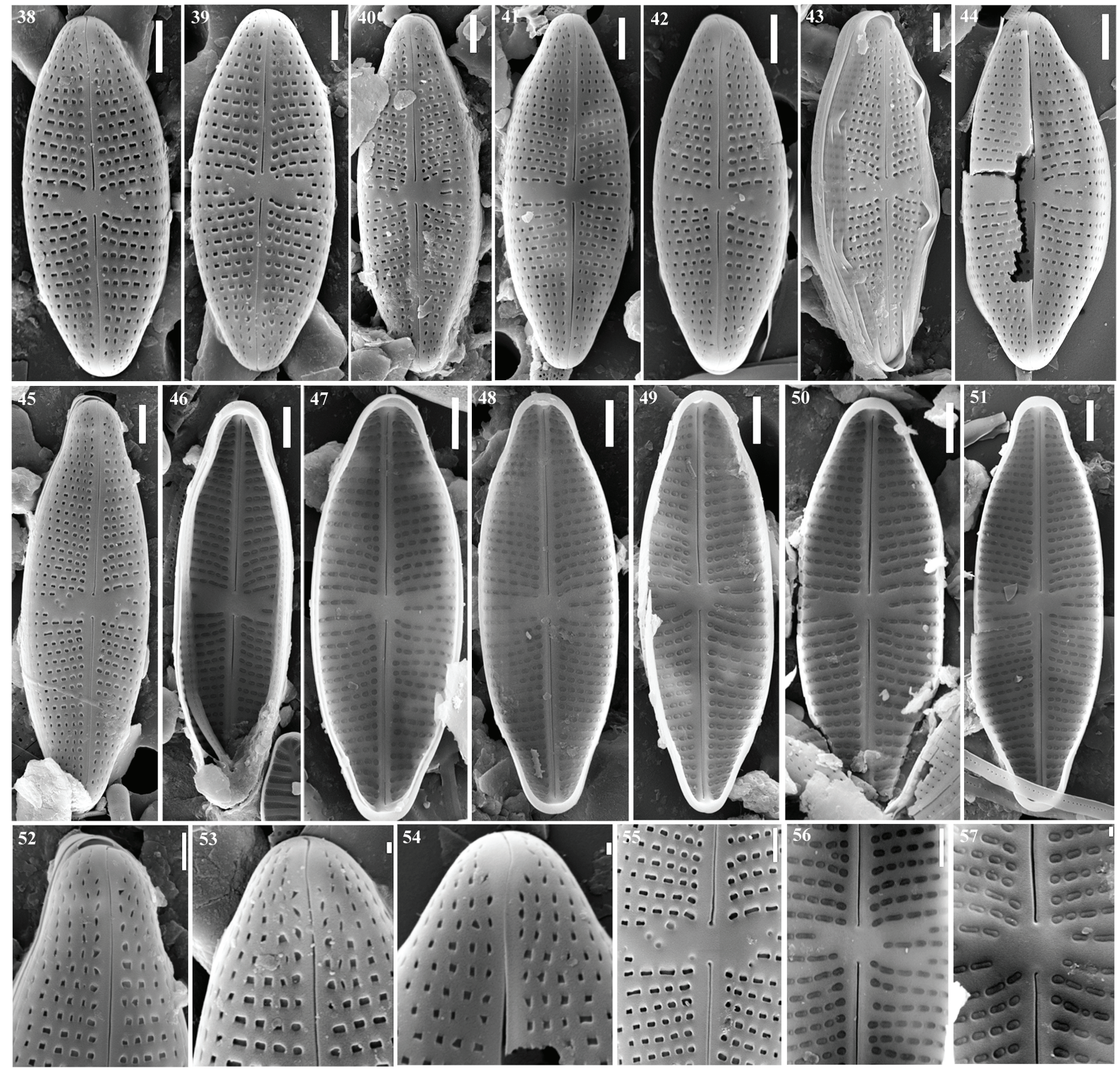

Figure 38-57. Dorofeyukea rostellata found in the Croatian lakes. SEM micrographs from Tribalj Lake. Scale bar $=2 \mu \mathrm{m}$ for Figs 38-51; $1 \mu \mathrm{m}$ for Figs 52, 55, 56 and $200 \mathrm{~nm}$ for Figs 53, 54, 57. Especies encontradas en los lagos croatas. Fotografias MEB del lago Tribalj. Escala $=2$ um para las figuras 38-51; 1 um para las figuras 52, 55, 56 y 200 nm para las figuras 53, 54 y 57. 
$\mathrm{n}=14$ ). The axial area is relatively broad (Figs. 38-51). Internally, the raphe fissures are straight, terminating in small helictoglossae near the poles (Figs. 46-51). Narrow pseudoseptum is present on both apices (Figs. 46-51).

\section{Investigation of type material of Dorofeyukea} rostellata (Hustedt) Kulikovskiy \& Kociolek (Figs. 14-24, 58-67)

In LM the valve is lanceolate with capitate or rostrate apices. The length of the valve is 14.6-39.1 $\mu \mathrm{m}$ (mean $=24.1 \pm 4.5 \mu \mathrm{m}, \mathrm{n}=55)$, the width is $6.6-10.4 \mu \mathrm{m}$ (mean $=8.1 \pm 0.8 \mu \mathrm{m}, \mathrm{n}=$ 55). Striae are radial, becoming slightly convergent on the apices. Number of striae is 17-25 in $10 \mu \mathrm{m}($ mean $=20.2 \pm 1.4, \mathrm{n}=55)$ and it can be denser toward the ends. Areolae are thin and drop-like and can easily be counted in LM. The number of areolae is $20-32$ in $10 \mu \mathrm{m}$ (mean = $24.5 \pm 2.4, \mathrm{n}=55$ ). The raphe is straight. There is no stigma on the valve surface.

In SEM externally, the areolae are transapically slit-like continuing on the mantle (Fig. 66). Internally, the areolae are mostly round, some of them are oval; they are closed by hymen (Figs. $63-65,67)$. The striae can be shorter or longer near the central area and become denser toward the ends. Striae are radial, slightly convergent on the apices. The axial area is relatively broad and become wider near the field of central area (Fig. 63). Raphe is straight; externally, distal raphe endings are bent to the same side (Figs. 58-62). The proximal raphe fissures are straight and slightly drop-shaped on the outer valve (Fig. 66), dot-like on the inner valve (Fig. 67). Internally, the distal raphe endings are straight, terminating in small helictoglossae near the poles (Figs. 63-65). Central area is transapically oval outside and fairly irregular inside.

Holotype: Ground slime of Telaga Pasir, middle Java. Isotype: warm springs of Kadjaj, central Sumatra. Hustedt F. 1937. Arch. Hydrobiol. Suppl. 15: 236, pl. 17, fig. 13. QH90A67s, Figured also in Schmidt's Atlas, pl. 405, figs 30-34.

Lectotype: N3/45. Sumatra. Warme Quelle v. Kadjaj. SKW2bo, Simonsen, R. 1987. Atlas and catalogue of the diatom types of Friedrich
Hustedt: 201, pl. 310, figs 6-10 (this material was investigated and illustrated in our study).

Isolectotype: N3/46. Sumatra. Warme Quelle v. Kadjaj. SKW2ba, Simonsen, R. 1987. Atlas and catalogue of the diatom types of Friedrich Hustedt: 201.

\section{Investigation of type material of Navicula grimmeioides H.P. Gandhi (Figs. 25-37, 68-81)}

In LM, the valve outline is lanceolate with capitate or rostrate apices. The length of the valve is $16.8-22.6 \mu \mathrm{m}$ (mean $=18.7 \pm 2.0, \mathrm{n}=$ 20 ), the width is $5.2-6.1 \mu \mathrm{m}$ (mean $=5.4 \pm 0.4, \mathrm{n}$ $=20$ ). Striae are radial throughout the valve, their number is $18-26$ in $10 \mu \mathrm{m}$ (mean = $21.4 \pm 2.7, \mathrm{n}=20$ ). They are composed of observable but hardly to analyse coarse areolae. Central area is round. The raphe is straight. There is no stigma on the valve.

In SEM, externally, the areolae are transapically elongated, thin or slit-like (Figs. 77, 78). The number of areolae is $25-35$ in $10 \mu \mathrm{m}$ (mean = $32.1 \pm 3.2, \mathrm{n}=10)$. They are arranged in single rows of striae that continue on the mantle (Figs. $78,81)$. Central area is round. Axial area is relatively broad and irregular. Raphe runs straight with bending distal endings. The proximal raphe fissures are strongly drop-shaped (Fig. 72).

Internally, the areolae are mostly round, some are oval which are closed by a hymen (Figs. 69, $70,73,79-81)$. The distal raphe endings are straight (Figs. 77, 78), terminating in small helictoglossae near the poles (Fig. 79). Proximal raphe fissures are slightly deflected to the same side (Figs. 74, 75).

Lectotype (designated here):-[illustration] Figs. 73-75 in p. 41, pl. 2 in Gandhi (1998: 324).

Type material: Lake Chandola border side with Ceratophyllum, Ahmedabad, India. Sample collected by H.P. Gandhi on 17 April 1960. Gandhi labelled this sample as "Sr-185 Ahmedabad: Lake Chandola border side with Ceratophyllum, a further spot cleaned 17-4-1960". Gandhi, H.P. (1998). Fresh-water Diatoms of Central Gujarat. Dehra Dun, India: Bishen Singh Mahendra Pal Singh, pl. 2, figs. 73-75. 

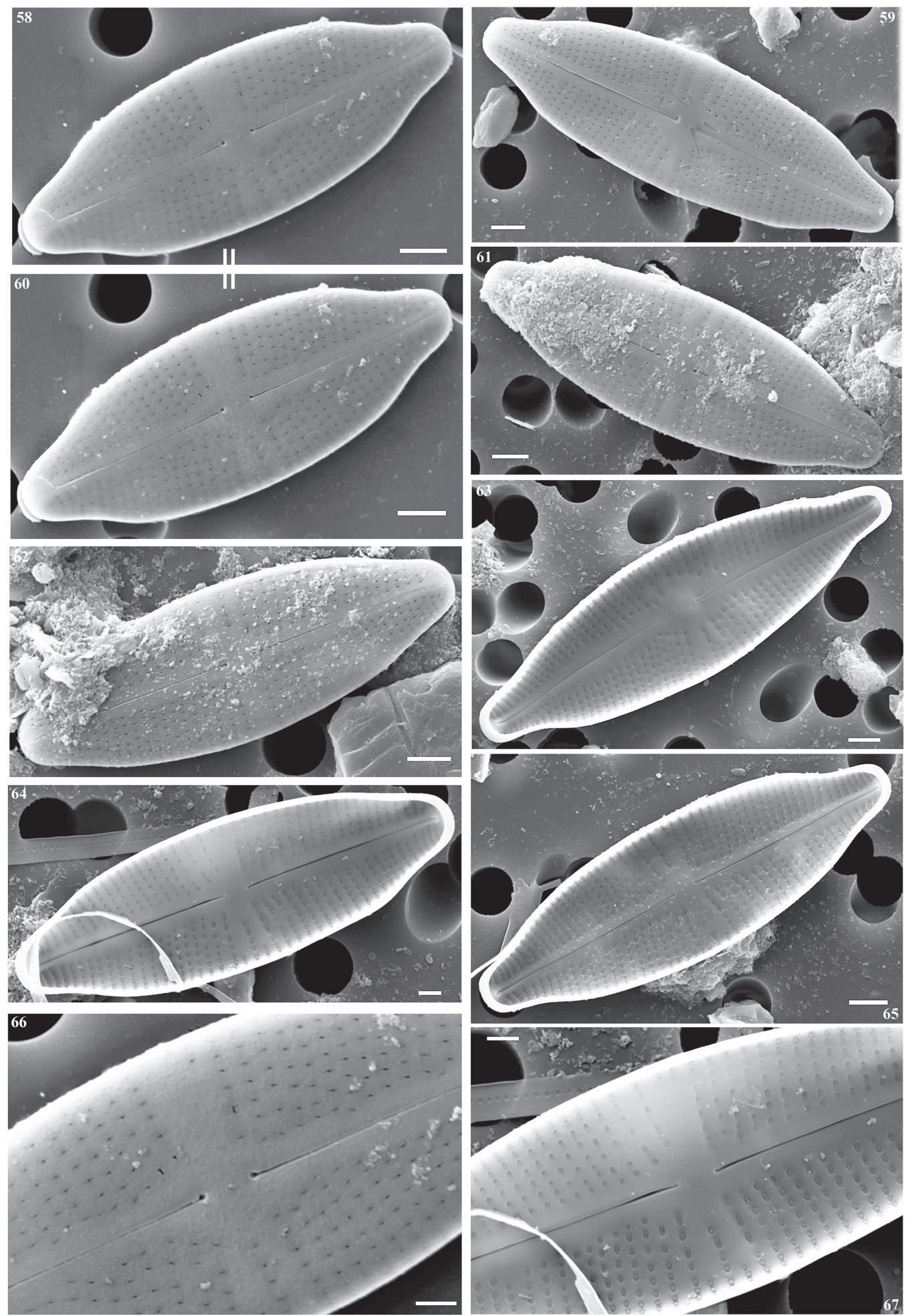

Figure 58-67. Dorofeyukea rostellata. SEM micrographs of the type material. Scale bar $=2 \mu \mathrm{m}$ for Figs $58-63,65 ; 1 \mu \mathrm{m}$ for Figs 64 , 66, 67. Dorofeyukea rostellata. Micrografías MEB del material tipo. Barra de escala $=2 \mu \mathrm{m}$ para las figuras 58-63, 65; 1 mm para las figuras $64,66,67$. 

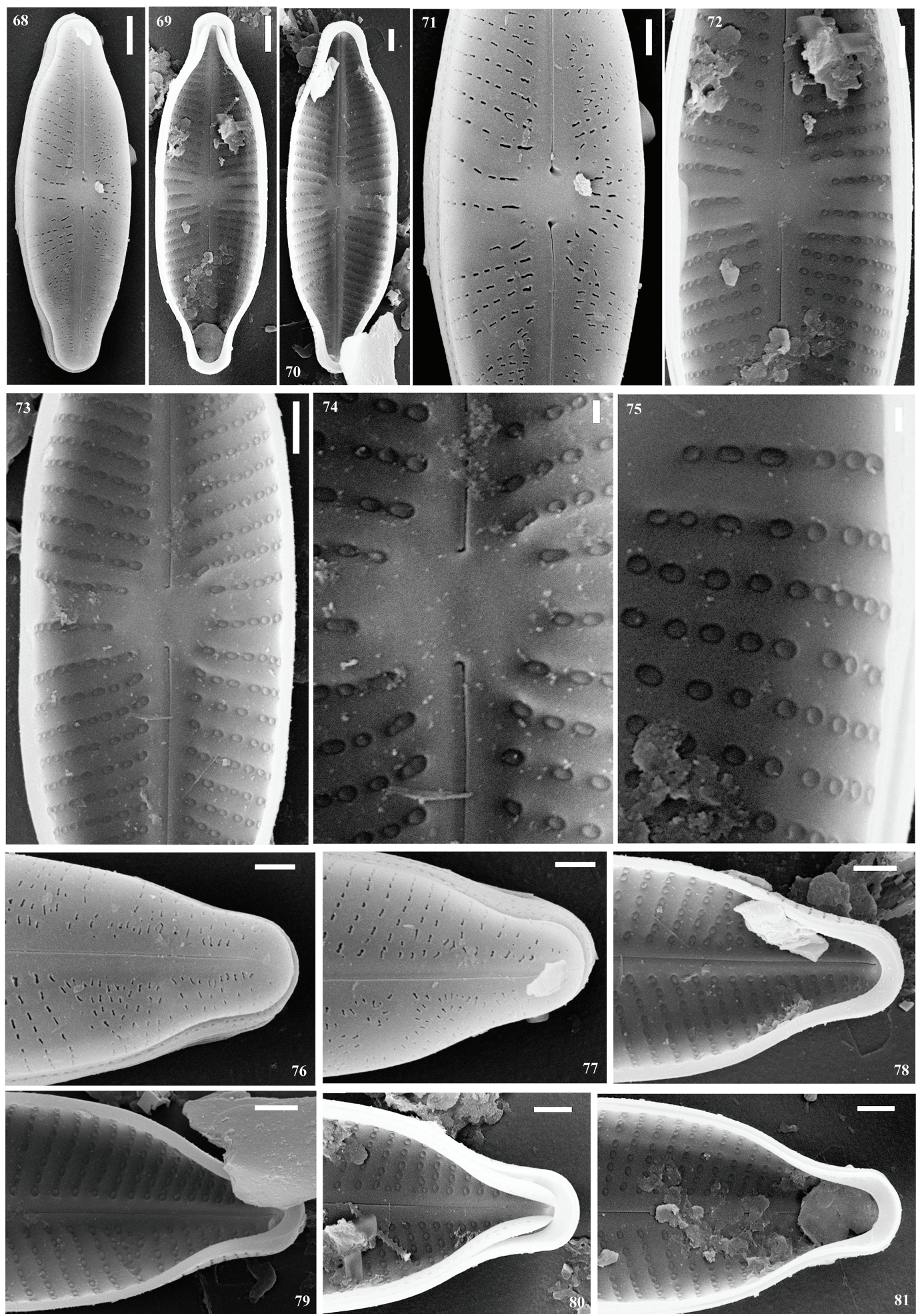

Figure 68-81. Dorofeyukea grimmeioides. SEM micrographs of the type material. Scale bar $=2 \mu \mathrm{m}$ for Figs 68,$69 ; 1 \mu \mathrm{m}$ for Figs 71-73, 76-81; $200 \mathrm{~nm}$ for Figs 74, 75. Dorofeyukea grimmeioides. Micrografias MEB del material tipo. Barra de escala $=2 \mu \mathrm{m}$ para las Figuras 68, 69; 1 um para las figuras 71-73, 76-81; $200 \mathrm{~nm}$ para las figuras 74, 75. 


\section{Habitat and ecology}

Dorofeyukea rostellata populations were found in two Croatian lakes with similar physical and chemical characteristics (Table 1). Both lakes were oligotrophic, oligosaprobic and situated in calcareous bedrock; COD values were below 2 $\mathrm{mg} / \mathrm{L}$ and oxygen saturation was always more than $85 \%$. The water of the lakes is neutral to slightly alkaline with $\mathrm{pH} 7.66$ (Ričice), 7.12 and 7.53 (Tribalj1, Tribalj3, respectively) and with low conductivity $(255 \mu \mathrm{S} / \mathrm{cm}$ for Lake Ričice; $241 \mu \mathrm{S} / \mathrm{cm}$ for Lake Tribalj1 and $243 \mu \mathrm{S} / \mathrm{cm}$ for Lake Tribalj3). The studied taxon occurred in the northern and in the eastern part of Tribalj, and in the northern part of Ričice. They occurred with low relative abundances $(0.96 \%$ in Lake Ričice, $1.68 \%$ in the eastern part and $0.49 \%$ in the northern part of Lake Tribalj). Achnanthidium straubianum (Lange-Bertalot) Lange-Bertalot was the only species that reached relatively high abundance in all three samples, it was subdominant in Lake Ričice $(4.34 \%)$ and dominant in Lake Tribalj with $6.49 \%$ and $10.73 \%$ of relative abundance in northern and in the eastern part of the lake. In Lake Ričice the dominant species were Amphora inariensis Krammer (36.14\%), Cavinula cocconeiformis (W. Gregory ex Greville) D.G. Mann \& Stickle in Round et al. $(10.12 \%)$ and Pantocsekiella ocellata (Pantocsek) K.T. Kiss \& Ács (26.02 \%). In Lake Tribalj the dominant species were Achnanthidium minutissimum (Kützing) Czarnecki (north part 18.03 $\%$ and east part $21.46 \%$ ), Encyonopsis subminuta Krammer \& E. Reichardt (north part $12.74 \%$ and east part $15.85 \%$ ) and Ulnaria delicatissima (W. Smith) Aboal \& P.C. Silva (north part $11.3 \%$ and east part $16.59 \%$ ).

\section{DISCUSSION}

Comparing the Croatian population with the type material of Dorofeyukea rostellata revealed differences in valve, central area and the areola shape, and the width and shape of the axial area. In SEM it can be seen that areolae of the Croatian population are mostly rectangular or square shaped in the middle (Fig. 55) and perpendicularly elongated toward the ends (Figs. 52-54) in external view, while that of $D$. rostellata are transapically slit-like (Figs. 58-62, 66). Furthermore, the axial area of the Croatian population is narrow and regular (Figs. 38-51), whereas it is wide and irregular in case of the type material of D. rostellata (Figs. 60, 63-65). However, as they overlapped with each other in the most important characteristics: valve apices and outline, striation, stria and areola density (Fig. 82), we cannot distinguish them as distinct taxa.

The presented Croatian population of Dorofeyukea rostellata resembles Navicula grimmei Krasske, a species described from Hessen, Germany (Krasske, 1925: 45, fig. 1: 14). Navicula grimmei had been synonymized to Navicula kotschyi (Krasske) Grunow (1860: 538, fig. 2: 12) by Krammer \& Lange-Bertalot (1986). Navicula kotschyi was also transferred to Dorofeyukea genus by Kulikovskiy et al. (2019). Dorofeyukea kotschyi (Grunow) Kulikovskiy, Kociolek, Tusset \& T.A.V. Ludwig differs from the Croatian population because $D$. kotschyi has more capitate ends and the areola density is 20-24 in 10 $\mu \mathrm{m}$ (Tyree \& Bishop, 2015), while the Croatian population has denser areolae, 24-30 in $10 \mu \mathrm{m}$ (Table 2). Furthermore, the areolae of D. kotschyi are uniform throughout the valve (Tyree \& Bishop, 2015), whereas they are narrow and transapically elongated toward the apices in the Croatian population. Kulikovskiy et al. (2019) ignored that Navicula grimmei was synonymized to Navicula kotschyi and they transferred the species into Dorofeyukea genus. But they used an incorrect reference as its basionym, so Dorofeyukea grimmei (Krasske in Hustedt) Kulikovskiy \& Kociolek is invalid at this moment according to the "International Code of Nomenclature for Algae, Fungi and Plants" (McNeill et al., 2012). Kulikovskiy et al. (2019) described a new species Dorofeyukea indokotschyi Kulikovskiy, Maltsev, Andreeva \& Kociolek, which is a closely relative of $D$. kotschyi; but Dorofeyukea indokotschyi has definitely more capitate ends than the Croatian population.

The Croatian population differs from Navicula grimmeioides (Gandhi, 1998: 324, fig. 41: 73-75) by the following characteristics: valve apices, shape of the central area, striation and areola shape. The Croatian population has less 

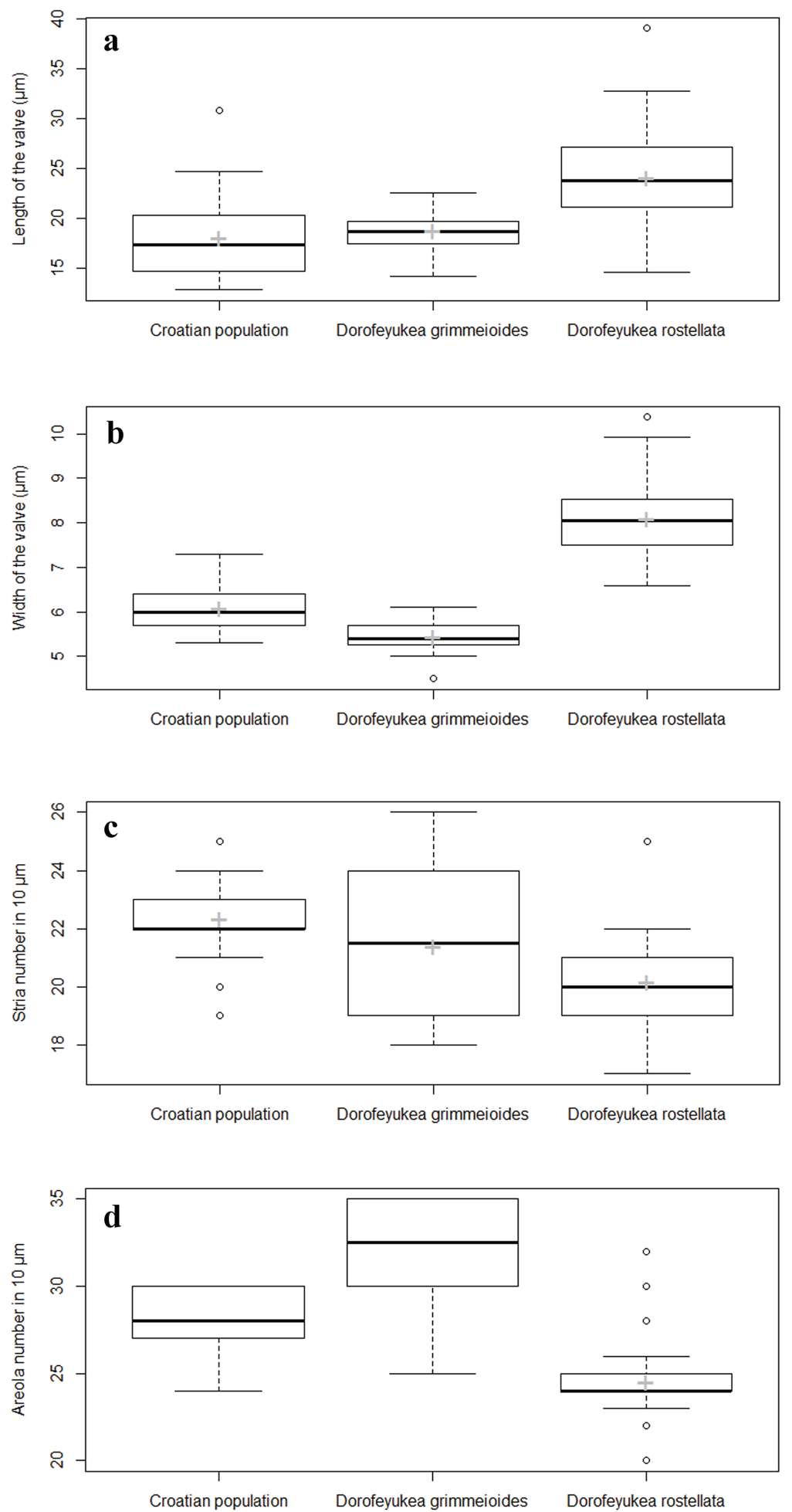

Figure 82. Box plots of length (a), width (b), striae (c) and areola number (d) in $10 \mu \mathrm{m}$ of the two investigated type material and the Croatian population. The grey cross on the box marks the mean of the metrics. Diagramas de cajas de longitud (a), ancho (b), estrias (c) y areola (d) en $10 \mu \mathrm{m}$ de los dos materiales investigados y la población croata. La cruz gris en el cuadro marca la media de las métricas. 
Table 2. Differential diagnosis of the Croatian population and related taxa. Diagnóstico diferencial de la población croata y taxones relacionados.

\begin{tabular}{|c|c|c|c|c|c|c|c|c|c|c|}
\hline & $\begin{array}{l}\text { Length } \\
(\mu \mathrm{m})\end{array}$ & $\begin{array}{l}\text { Width } \\
(\mu \mathrm{m})\end{array}$ & $\begin{array}{l}\text { Striae in } 10 \\
\mu \mathrm{m}\end{array}$ & $\begin{array}{l}\text { Areolae } \\
\text { (shape and } \\
\text { number in } 10 \\
\mu \mathrm{m} \text { ) }\end{array}$ & $\begin{array}{l}\text { Valve } \\
\text { outline }\end{array}$ & Axial area & Raphe & Central area & Biogeography & References \\
\hline $\begin{array}{l}\text { Croatian } \\
\text { population }\end{array}$ & $12.8-30.8$ & $5.3-7.3$ & $\begin{array}{l}19-25 \\
\text { radial } \\
\text { slightly } \\
\text { convergent } \\
\text { on the apices }\end{array}$ & $\begin{array}{l}(24) 25-30 \\
\text { elongated in } \\
\text { single rows } \\
\text { which } \\
\text { continue on } \\
\text { the mantle; } \\
\text { externally } \\
\text { rectangular, } \\
\text { transapically } \\
\text { elongated at } \\
\text { the central part } \\
\text { and slit-like on } \\
\text { the apices }\end{array}$ & $\begin{array}{l}\text { lanceolate } \\
\text { with slightly } \\
\text { capitate or } \\
\text { broadly } \\
\text { apices }\end{array}$ & narrow & $\begin{array}{l}\text { filiform; } \\
\text { raphe fissures } \\
\text { are straight, } \\
\text { internally } \\
\text { terminating in } \\
\text { small } \\
\text { helictoglossae } \\
\text { near the poles }\end{array}$ & $\begin{array}{l}\text { slightly } \\
\text { asymmetric } \\
\text { bowtie shape }\end{array}$ & $\begin{array}{l}\text { Tribalj and } \\
\text { Ričice, Croatia }\end{array}$ & present study \\
\hline $\begin{array}{l}\text { Dorofeyukea } \\
\text { ancisa (Hustedt) } \\
\text { Kulikovskiy \& } \\
\text { Kociolek (Hustedt } \\
\text { 1953: 48, pl. 150, } \\
\text { fig. 9) }\end{array}$ & 14 & $5-6$ & $\begin{array}{l}20 \\
\text { radiate, at } \\
\text { apices nearly } \\
\text { parallel }\end{array}$ & NA & $\begin{array}{l}\text { rectangular } \\
\text { with little } \\
\text { convex } \\
\text { edges }\end{array}$ & narrow & filiform & $\begin{array}{l}\text { small, } \\
\text { transapically } \\
\text { slightly } \\
\text { widened }\end{array}$ & $\begin{array}{l}\text { Oasis Gafsa, } \\
\text { southern Tunisia }\end{array}$ & Hustedt (1953) \\
\hline $\begin{array}{l}\text { Dorofeyukea } \\
\text { grimmei (Krasske } \\
\text { in Hustedt) } \\
\text { Kulikovskiy \& } \\
\text { Kociolek (Krasske } \\
\text { 1925, p. } 45, \text { pl. 1, } \\
\text { fig. 14) }\end{array}$ & $18-21$ & 6 & $\begin{array}{l}\text { 25 } \\
\text { the two } \\
\text { middle } \\
\text { shortened } \\
\text { and slightly } \\
\text { coarser; } \\
\text { towards the } \\
\text { ends become } \\
\text { narrower }\end{array}$ & $\begin{array}{l}\text { quite coarse } \\
(20-24)\end{array}$ & $\begin{array}{l}\text { elliptic- } \\
\text { lanceolate } \\
\text { with capitate } \\
\text { apices }\end{array}$ & narrow & NA & square & $\begin{array}{l}\text { Laurentian Great } \\
\text { Lakes, North } \\
\text { America }\end{array}$ & $\begin{array}{l}\text { Hustedt (1930), } \\
\text { Potapova (2013) }\end{array}$ \\
\hline $\begin{array}{l}\text { Dorofeyukea } \\
\text { grimmeioides (H.P. } \\
\text { Gandhi) Ács, } \\
\text { Buczkó \& Ector } \\
\text { comb. nov. } \\
\text { (Gandhi 1998: 324, } \\
\text { p. 41, figs 73-75) }\end{array}$ & $14.2-22.6$ & $4.5-6.1$ & $\begin{array}{l}18-26 \\
\text { radial }\end{array}$ & $\begin{array}{l}25-35 \\
\text { thin, } \\
\text { transapically } \\
\text { elongated, slit- } \\
\text { like; closed by } \\
\text { hymen in the } \\
\text { inner valve }\end{array}$ & $\begin{array}{l}\text { lanceolate } \\
\text { with capitate } \\
\text { or rostrate } \\
\text { apices }\end{array}$ & $\begin{array}{l}\text { relatively } \\
\text { broad }\end{array}$ & $\begin{array}{l}\text { straight, } \\
\text { proximal raphe } \\
\text { fissures strongly } \\
\text { drop-shaped }\end{array}$ & $\begin{array}{l}\text { round, } \\
\text { forming } \\
\text { narrow } \\
\text { stauroid fascia } \\
\text { with } 3 \\
\text { shortened } \\
\text { striae }\end{array}$ & Gujarat, India & $\begin{array}{l}\text { Gandhi (1998), } \\
\text { present study }\end{array}$ \\
\hline $\begin{array}{l}\text { Dorofeyukea } \\
\text { indokotschyi } \\
\text { Kulikovskiy, } \\
\text { Maltsev, Andreeva } \\
\text { \& Kociolek } \\
\text { (Kulikovskiy et al. } \\
\text { 2019: figs 2-4) }\end{array}$ & $25-26$ & $7-7.5$ & $\begin{array}{l}20-21 \\
\text { weakly } \\
\text { radiate, } \\
\text { almost } \\
\text { parallel at } \\
\text { the poles }\end{array}$ & rectangular & $\begin{array}{l}\text { elliptic to } \\
\text { linear } \\
\text { elliptic, ends } \\
\text { protracted, } \\
\text { abruptly } \\
\text { short- } \\
\text { rostrate }\end{array}$ & narrow & $\begin{array}{l}\text { filiform, central } \\
\text { pore small, } \\
\text { appearing as } \\
\text { puncta }\end{array}$ & $\begin{array}{l}\text { narrow } \\
\text { stauroid fascia } \\
\text { surrounded by } \\
1-3 \text { irregularly } \\
\text { shortened } \\
\text { striae }\end{array}$ & $\begin{array}{l}\text { Indonesia, Papua, } \\
\text { Lake Sentani }\end{array}$ & $\begin{array}{l}\text { Kulikovskiy et al. } \\
\text { (2019) }\end{array}$ \\
\hline $\begin{array}{l}\text { Dorofeyukea } \\
\text { ivatoensis } \\
\text { (Metzeltin \& } \\
\text { Lange-Bertalot) } \\
\text { Kulikovskiy \& } \\
\text { Kociolek } \\
\text { (Metzeltin \& } \\
\text { Lange-Bertalot } \\
\text { 2002: 286, pl. 27, } \\
\text { figs 6-10, pl. 28, } \\
\text { figs } 1-3 \text { ) }\end{array}$ & $18-34$ & $6.6-9.5$ & $\begin{array}{l}21-24 \\
\text { radiate, } \\
\text { proximally } \\
\text { becoming } \\
\text { subparallel, } \\
\text { finally } \\
\text { slightly } \\
\text { convergent } \\
\text { near the } \\
\text { poles; } \\
\text { stigma in the } \\
\text { central area } \\
\text { absent }\end{array}$ & $\begin{array}{l}15(20) \\
\text { rather coarse, } \\
\text { some } \\
\text { moderately } \\
\text { elongated } \\
\text { transapically } \\
\text { in the middle, } \\
\text { becoming } \\
\text { smaller and } \\
\text { denser } \\
\text { towards the } \\
\text { ends; } \\
\text { isodiametric } \\
\text { (punctiform) } \\
\text { to apically } \\
\text { elongated } \\
\text { (only in SEM } \\
\text { observed), the } \\
\text { areolae form } \\
\text { continuous } \\
\text { rows from the } \\
\text { valve face } \\
\text { over the } \\
\text { mantle }\end{array}$ & $\begin{array}{l}\text { elliptic, ends } \\
\text { shortly } \\
\text { protracted } \\
\text { broadly, } \\
\text { more or less } \\
\text { subcapitate, } \\
\text { finally } \\
\text { broadly } \\
\text { rounded }\end{array}$ & $\begin{array}{l}\text { linear, } \\
\text { narrow to } \\
\text { very } \\
\text { narrow, } \\
\text { not or very } \\
\text { little } \\
\text { broadened } \\
\text { to the } \\
\text { middle }\end{array}$ & $\begin{array}{l}\text { filiform, straight } \\
\text { with } \\
\text { inconspicuous } \\
\text { central pores, } \\
\text { broadly } \\
\text { deflected }\end{array}$ & $\begin{array}{l}\text { slightly } \\
\text { variable to } \\
\text { barely } \\
\text { developed; } \\
\text { mostly small, } \\
\text { circular or } \\
\text { elliptic }\end{array}$ & $\begin{array}{l}\text { "Island } \\
\text { Continent", } \\
\text { Madagascar }\end{array}$ & $\begin{array}{l}\text { Metzeltin \& } \\
\text { Lange-Bertalot } \\
(2002)\end{array}$ \\
\hline
\end{tabular}


Table 2. (cont.)

\begin{tabular}{|c|c|c|c|c|c|c|c|c|c|c|}
\hline $\begin{array}{l}\text { Dorofeyukea } \\
\text { kotschyi (Grunow) } \\
\text { Kulikovskiy, } \\
\text { Kociolek, Tusset \& } \\
\text { T.A.V. Ludwig } \\
\text { (Grunow 1860: } \\
\text { 538, pl. 2: fig. 12) }\end{array}$ & $\begin{array}{l}18-19 \\
18.0-25.3\end{array}$ & $\begin{array}{l}5-5.5 \\
6.0-8.1\end{array}$ & $\begin{array}{l}20-24 \\
\text { radiate, at } \\
\text { apices nearly } \\
\text { parallel } \\
\text { radiate }\end{array}$ & $\begin{array}{l}\text { coarse and } \\
\text { visible in LM } \\
\text { externally } \\
\text { round, } \\
\text { internally } \\
\text { transapically } \\
\text { linear }\end{array}$ & $\begin{array}{l}\text { linear with } \\
\text { parallel } \\
\text { central valve } \\
\text { margins and } \\
\text { distinctly } \\
\text { capitate } \\
\text { apices }\end{array}$ & $\begin{array}{l}\text { narrow and } \\
\text { linear }\end{array}$ & $\begin{array}{l}\text { filiform with } \\
\text { unilaterally } \\
\text { deflected distal } \\
\text { ends }\end{array}$ & $\begin{array}{l}\text { bowtie-shaped } \\
\text { with marginal } \\
\text { areolae }\end{array}$ & $\begin{array}{l}\text { Laurentian Great } \\
\text { Lakes, North } \\
\text { America }\end{array}$ & $\begin{array}{l}\text { Grunow (1860), } \\
\text { Potapova (2013), } \\
\text { Kulikovskiy et al. } \\
(2019)\end{array}$ \\
\hline $\begin{array}{l}\text { Dorofeyukea } \\
\text { orangiana (R.M. } \\
\text { Patrick) } \\
\text { Kulikovskiy \& } \\
\text { Kociolek (Patrick } \\
\text { 1959: 97, pl. 8, fig. } \\
\text { 4) }\end{array}$ & $17-22$ & $5-7$ & $\begin{array}{l}18-20 \\
\text { (towards the } \\
\text { ends 26) } \\
\text { radiate, } \\
\text { distinctly } \\
\text { punctate }\end{array}$ & $\begin{array}{l}20-25 \\
\text { (Potapova } \\
2013 \text { ) }\end{array}$ & $\begin{array}{l}\text { linear- } \\
\text { lanceolate } \\
\text { with narrow, } \\
\text { rostrate, } \\
\text { rounded } \\
\text { ends }\end{array}$ & $\begin{array}{l}\text { narrow, } \\
\text { widening } \\
\text { toward the } \\
\text { central } \\
\text { area }\end{array}$ & $\begin{array}{l}\text { proximal raphe } \\
\text { fissures strongly } \\
\text { drop-shaped }\end{array}$ & $\begin{array}{l}\text { rounded (more } \\
\text { or less) }\end{array}$ & $\begin{array}{l}\text { Sabine River, } \\
\text { Texas, Lake } \\
\text { Maurepas, } \\
\text { Lousiana, Ridley } \\
\text { Creek, } \\
\text { Pennsylvania, } \\
\text { Patuxent River, } \\
\text { Maryland }\end{array}$ & $\begin{array}{l}\text { Patrick (1959), } \\
\text { Potapova (2013) }\end{array}$ \\
\hline $\begin{array}{l}\text { Dorofeyukea } \\
\text { rostellata (Hustedt) } \\
\text { Kulikovskiy \& } \\
\text { Kociolek (Hustedt } \\
\text { 1937: 236, pl. 17, } \\
\text { fig. 13) }\end{array}$ & $14.6-39.1$ & $\begin{array}{l}6.6- \\
10.4\end{array}$ & $\begin{array}{l}17-25 \\
\text { radial, } \\
\text { slightly } \\
\text { convergent } \\
\text { on the apices }\end{array}$ & $\begin{array}{l}20-32 \\
\text { externally slit- } \\
\text { like }\end{array}$ & $\begin{array}{l}\text { lanceolate } \\
\text { with capitate } \\
\text { or rostrate } \\
\text { apices }\end{array}$ & broad & $\begin{array}{l}\text { straight, } \\
\text { proximal raphe } \\
\text { fissures slightly } \\
\text { drop-shaped }\end{array}$ & $\begin{array}{l}\text { transapically } \\
\text { oval on the } \\
\text { outer and } \\
\text { irregular on } \\
\text { the inner } \\
\text { valve, forming } \\
\text { narrow } \\
\text { stauroid fascia } \\
\text { with 2-3 } \\
\text { irregularly } \\
\text { shortened } \\
\text { striae }\end{array}$ & $\begin{array}{l}\text { Java, Bali, } \\
\text { Sumatra }\end{array}$ & $\begin{array}{l}\text { Hustedt (1937), } \\
\text { and own } \\
\text { measurements }\end{array}$ \\
\hline $\begin{array}{l}\text { Dorofeyukea } \\
\text { savannahiana } \\
\text { (R.M. Patrick) } \\
\text { Kulikovskiy \& } \\
\text { Kociolek (Patrick } \\
\text { 1959: 97, pl. 8, fig. } \\
\text { 7) }\end{array}$ & $17-22$ & $4-5$ & $20-22$ & $\begin{array}{l}24-28 \\
\text { (Potapova } \\
2013 \text { ) } \\
\text { radiate, } \\
\text { distinctly } \\
\text { punctate }\end{array}$ & $\begin{array}{l}\text { linear with } \\
\text { distinctly } \\
\text { capitate ends }\end{array}$ & narrow & $\begin{array}{l}\text { straight, } \\
\text { proximal raphe } \\
\text { fissures slightly } \\
\text { drop-shaped }\end{array}$ & $\begin{array}{l}\text { transverse, not } \\
\text { reaching the } \\
\text { margin of the } \\
\text { valve }\end{array}$ & $\begin{array}{l}\text { Savannah River, } \\
\text { United States }\end{array}$ & $\begin{array}{l}\text { Patrick (1959), } \\
\text { Potapova (2013) }\end{array}$ \\
\hline $\begin{array}{l}\text { Dorofeyukea } \\
\text { texana (R.M. } \\
\text { Patrick) } \\
\text { Kulikovskiy \& } \\
\text { Kociolek (Patrick } \\
\text { 1959: 98, pl. 8, fig. } \\
\text { 5) }\end{array}$ & $18-22$ & $5-7$ & $18-21$ & $\begin{array}{l}20-27 \\
\text { (Potapova } \\
2103 \text { ) } \\
\text { irregularly } \\
\text { shortened on } \\
\text { each side of } \\
\text { the central } \\
\text { nodule; } \\
\text { parallel at } \\
\text { apices of the } \\
\text { valve, } \\
\text { otherwise } \\
\text { radiate; } \\
\text { distinctly } \\
\text { punctate }\end{array}$ & $\begin{array}{l}\text { margins are } \\
\text { parallel with } \\
\text { narrowed, } \\
\text { distinctly } \\
\text { rostrate ends }\end{array}$ & narrow & $\begin{array}{l}\text { straight with } \\
\text { slightly } \\
\text { unilaterally } \\
\text { deflected } \\
\text { proximal ends }\end{array}$ & transverse & $\begin{array}{l}\text { Guadalupe River, } \\
\text { United States }\end{array}$ & $\begin{array}{l}\text { Patrick (1959), } \\
\text { Potapova (2013) }\end{array}$ \\
\hline
\end{tabular}

capitate apices, especially the smaller specimens (Figs. 55, 56), than N. grimmeioides. Striae of the Croatian population are radial but become convergent on the apices (Figs. 2-13). Furthermore, its striae can be longer or shorter in the central part (Figs. 40-42) forming a bowtie shape central area, while in the case of $N$. grimmeioides striae are radial throughout the valve and the central area is round (Figs. 25-37, 73-75). In SEM the Croatian population has rectangular areolae (Figs. 55-57), which become lineolate-like toward the apices (Figs. 52-54) whilst that of in case of $N$. grimmeioides has transapically slit-like areolation (Figs. 68-70). Externally, the proximal raphe ends of the Croatian popu- lation are dot-like fissures (Figs. 38-45, 55) while drop-shaped in case of $N$. grimmeioides (Fig. 72).

Based on the description of Dorofeyukea genus (Kulikovskiy et al., 2019), N. grimmeioides also belongs to Dorofeyukea, because its central area forming narrow stauroid fascia (Figs. 68-70), surrounded with 2-3 shortened striae, its areolae covered internally by dome-shaped hymens (Figs. 74, 75), distal raphe ends hook-shaped going to mantle (Fig. 76), and it has pseudoseptum at distal ends (Figs. 69, 70, 78-81). Judging by morphological characteristics, we propose the transfer of $N$. grimmeioides to the genus Dorofeyukea as follows: 


\section{Dorofeyukea grimmeioides (H.P. Gandhi) Ács, Buczkó \& Ector comb. nov.}

Basionym: Navicula grimmeioides H.P. Gandhi 1998, Bishen Singh Mahendra Pal Singh. Dehra Dun. India 324, p. 41, pl. 2, figs. 73-75.

Some other species, as Dorofeyukea texana (R.M. Patrick) Kulikovskiy \& Kociolek (Patrick 1959: 98, fig. 8: 5) also resembles the Croatian population, but its areolae on the central part are not elongated transversally. Dorofeyukea savannahiana (R.M. Patrick) Kulikovskiy \& Kociolek (Patrick 1959: 97, fig. 8: 7) have more capitate ends. According to Potapova (2013), it is possible that Dorofeyukea kotschyi is rather variable in valve outline, shape and density of areolae, and width of the pseudoseptum and both $D$. texana and D. savannahiana are conspecific with it. Kulikovskiy et al. (2019) refer them as valid species. Potapova (2013) was not able to distinguish pseudoseptae in D. savannahiana. Narrow pseudoseptum is present on both apices in case of the Croatian population. Dorofeyukea orangiana (R.M. Patrick) Kulikovskiy \& Kociolek (Patrick 1959: 97, fig. 8: 4) and Dorofeyukea ivatoensis (Metzeltin \& Lange-Bertalot) Kulikovskiy \& Kociolek (Metzeltin \& Lange-Bertalot 2002: 286, figs. 27: 6-10, 28: 1-3) have round central area. In addition, the central area of $D$. ivatoensis is small and its distal raphe end is curved. The central area of Dorofeyukea ancisa (Hustedt) Kulikovskiy \& Kociolek (Hustedt 1953: 150, fig. 9) is smaller than that of Croatian population (Table 2).

Our study pointed out that investigation of the type materials can be very important, particularly in case of rare taxa. We also want to stress here that the intensive studies on diatom taxonomy using high-resolution microscopic techniques, for better understanding of the ultrastructure of diatom frustule, can lead to new species description or combination of species. Although SEM analyses also revealed that the studied taxa do not belong to the genus Navicula sensu stricto, molecular data are important for erecting a new genus.

\section{SUMMARY}

Dorofeyukea rostellata is a rare diatom, known from various habitats. Here we reported the first
European occurrence of this diatom. Detailed ultrastructural investigations of the type material of Navicula grimmeioides, which resemble to Dorofeyukea rostellata, revealed that its characteristics fit the main features of the genus Dorofeyukea, so we proposed to transfer it into the genus Dorofeyukea as a new combination.

\section{ACKNOWLEDGEMENTS}

The authors are thankful to Bánk Beszteri (Alfred Wegener Institute, Bremerhaven, Germany) for sending the Hustedt type material of Navicula grimmei var. rostellata. The authors are also thank Prof.dr.sc. Zlatko Mihaljević for leadering the project, dr.sc. Igor Stanković for supporting with maps, all those who sampled cross Croatia and Hrvatske Vode to provide physical and chemical parameters. We thank Diba Khan-Bureau (Three Rivers Community College, Norwich, Connecticut, USA) for her precious English corrections. Funding for this research was partly provided in the framework of the DIATOMS project (LIST - Luxembourg Institute of Science and Technology). The samplings have been managed in the frame of the project Development of a System for Classifying the Ecological Potential for artificial and heavily modified surface water bodies in Croatia (Part 1. Reservoirs of Pannonian Ecoregion and Part 2. Reservoirs of Dinaric Ecoregion). BK thanks the Director, Agharkar Research Institute, Pune. The present work is supported by institute's core activity (Diatom Herbarium, BD-07). This work was also supported by the National Research, Development and Innovation Office - NKFIH (OTKA 119208, CRYPTIC project).

\section{REFERENCES}

BARBOUR, M. T., J. GERRITSEN, B. D. SNYDER \& J. B. STRIBLING. 1999. Rapid bioassessment protocols for use in streams and wadeable rivers: periphyton, benthic macroinvertebrates and fish. Second Edition. EPA 841-B-99-002. United States Environmental Protection Agency, Office of Water, Washington, D.C.

CEN. 2014. Water quality - Guidance for the 
routine sampling and preparation of benthic diatoms from rivers and lakes. EN 13946. Comité Européen de Normalisation, Bruxelles, Geneva, pp. 1-14. DOI: 10.3403/30247820

GANDHI, H. P. 1998. Fresh-water diatoms of Central Gujarat. Bishen Singh Mahendra Pal Singh. Dehra Dun. India. 324 pp.

GRUNOW, A. 1860. Ueber neue oder ungenügend gekannte Algen. Erste Folge. Diatomaceen, Familie Naviculaceen. Verhandlungen der Kaiserlich-Königlichen Zoologisch-Botanischen Gesellschaft in Wien, 10: 503-582.

HUSTEDT, F. 1930. Bacillariophyta (Diatomeae) Zweite Auflage. In: Die Süsswasser-Flora Mitteleuropas. Heft 10. A. Pascher (ed.): pp. [i]-vii, [1]-466. Verlag von Gustav Fischer, Jena.

HUSTEDT, F. 1937. Systematische und ökologische Untersuchungen über die Diatomeen-Flora von Java, Bali und Sumatra nach dem Material der Deutschen Limnologischen Sunda-Expedition "Tropische Binnengewässer, Band VII". Archiv für Hydrobiologie, Supplement, 15 (2): 187-295.

HUSTEDT, F. 1953. Diatomeen aus der Oase Gafsa in Südtunesien, ein Beitrag zur Kenntnis der Vegetation afrikanischer Oasen. Archiv für Hydrobiologie, 48: 145-153.

KIM, W. H. \& B.-K. PARK. 1988. Marine diatoms from the late Quarternary sediments in the Marian Cove, King George Island, Antarctica. Journal of the Paleontological Society of Korea, 4: 135-159.

KRAMMER, K. \& H. LANGE-BERTALOT. 1986. Bacillariophyceae. 1. Teil: Naviculaceae. In: Süßwasserflora von Mitteleuropa, Band 2/1. H. Ettl, J. Gerloff, H. Heynig \& D. Mollenhauer (eds): Gustav Fischer Verlag. Stuttgart, New York. 876 pp.

KRASSKE, G. 1925. Die Bacillariaceen-Vegetation Niederhessens. Abhandlungen und Bericht LVI des Vereins für Naturkunde zu Cassel, 84-89 Vereinsjahr 1919-1925, 56: 1-119.

KULIKOVSKIY, M., Y. MALTSEV, S. ANDREEVA, A. GLUSHCHENKO, E. GUSEV, Y. PODUNAY, T. V. LUDWIG, E. TUSSET \& J. P. KOCIOLEK. 2019. Description of a new diatom genus Dorofeyukea gen. nov. with remarks on phylogeny of the family Stauroneidaceae. Journal of Phycology, 55: 173-185. DOI: 10.1111/jpy. 12810

McNEILL, J., F. R. BARRIE, W. R. BUCK, V. DEMOULIN, W. GREUTER, D. L. HAWKSWORTH, P. S. HERENDEEN, S. KNAPP, K. MARHOLD, J. PRADO, W. F. PRUD'HOMME VAN REINE, G. F. SMITH, J. H. WIERSEMA \& N. J. TURLAND. 2012. International Code of Nomenclature for Algae, Fungi, and Plants (Melbourne Code). Regnum Vegetabile, 154: 1-208.

METZELTIN, D. \& H. LANGE-BERTALOT. 2002. Diatoms from the "Island Continent" Madagascar. Iconographia Diatomologica, 11: $1-286$.

NARODNE NOVINE, 2013. Uredba o standardu kakvoće voda [Regulation on water quality standard], (in Croatian), 73/13.

NARODNE NOVINE, 2014. Uredba o izmjenama i dopunama Uredbe o standardu kakvoće voda [Regulation of modification of Regulation on water quality standard] (in Croatian), $151 / 14$.

NARODNE NOVINE, 2015. Uredba o izmjenama i dopunama Uredbe o standardu kakvoće voda [Regulation of modification of Regulation on water quality standard] (in Croatian), $78 / 15$.

PATRICK, R. 1959. New species and nomenclatural changes in the genus Navicula (Bacillariophyceae). Proceedings of the Academy of Natural Sciences of Philadelphia, 111: 91-108.

POTAPOVA, M. 2013. The types of 22 Navicula (Bacillariophyta) species described by Ruth Patrick. Proceedings of the Academy of Natural Sciences of Philadelphia, 162: 1-23. DOI: 10.1635/053.162.0101

SIMONSEN, R. 1987. Atlas and catalogue of the diatom types of Friedrich Hustedt. Vol. 1: 525 pp., Vol. 2: pls 1-395, Vol. 3: pls 396-772. J. Cramer, Gebrüder Borntraeger. Berlin \& Stuttgart.

SMITH, T. E., C. J. SMITH \& T. N. Y. ANNANG. 2015. Taxonomic catalogue of algae from Ghana (Africa) and new additions. Algae Press. Ave Maria, Florida, USA. 101 pp. TYREE, M. \& I. BISHOP. 2015. Navicula 
kotschyi. In Diatoms of the United States. Retrieved November 01, 2017, from https://
diatom.ansp.org/algae_image/Image.aspx? imageid=IM003813

Con el apoyo de: 